\title{
Bacteriophage Therapy: Recent Development and Applications
}

\author{
Ali Raza ${ }^{1}$, Maria jamil ${ }^{2}$, Muhammad Tahir Aleem ${ }^{3,4^{*}}$, Muhammad Aamir Aslam ${ }^{1}$, Hafiz Muhammad Ali ${ }^{5}$, Sara khan ${ }^{1}$ \\ Namra Kareem ${ }^{6}$, Tehzeeb Asghar ${ }^{1}$, Kainat Gul $^{1}$, Hamna Nadeem ${ }^{1}$, Juon Abbass ${ }^{1}$, Sarfraz Khan ${ }^{1}$ \\ ${ }^{1}$ Institute of Microbiology, University of Agriculture, Faisalabad, Punjab, Pakistan \\ ${ }^{2}$ Department of Pathology, University of Agriculture, Faisalabad, Pakistan \\ ${ }^{3}$ MOE Joint International Research Laboratory of Animal Health and Food Safety, College of Veterinary Medicine, Nanjing \\ Agricultural University, 210095 Nanjing, P.R. China \\ ${ }^{4}$ Department of parasitology, University of Agriculture, Faisalabad, Pakistan \\ ${ }^{5}$ Faculty of Veterinary and Animal Sciences, The Islamia University of Bahawalpur, Pakistan \\ ${ }^{6}$ Department of Pathobiology, Bahauddin Zakariya University, Multan, Pakistan
}

*Corresponding author: Muhammad Tahir Aleem

\section{Abstract}

For centuries, mankind is dealing with deadly infectious diseases. Broad-spectrum antibiotics are commonly used against these bacterial infections. However, due to the excessive use of antibiotics, several bacteria have developed resistance against these therapies. Many advanced methods are being developed to overcome this issue, wherein bacteriophage therapy is included at the top of the list. Bacteriophages are "bacteria-eating viruses", have more sensitivity, specificity, host range, and efficacy than antibiotics, and are now being used as an antibiotic replacer in different food items, guarding pregnancy, treating surgical wounds, and protecting aquaculture. Bacteriophages are currently being synthesized and commercialized in all three; solid, liquid, gas forms. Due to continuous mutation in bacterial genomics, different modifications are being applied, like crisper and endolysin that increase the efficiency of bacteriophages and decrease the survival probability of the bacteria to its minimal level. The current text will elaborate on the recent advancements and applications of bacteriophage therapy in eliminating bacterial infections, especially in the food and aquaculture industry, and due to its increased therapeutic applications, considered to be a strong candidate to prove its true potential.

Keywords: Bacteriophage, phage therapy, crisper, endolysin, food industry, aquaculture.

Copyright () 2021 The Author(s): This is an open-access article distributed under the terms of the Creative Commons Attribution 4.0 International License (CC BY-NC 4.0) which permits unrestricted use, distribution, and reproduction in any medium for non-commercial use provided the original author and source are credited.

\section{The General Concept of Phage Therapy}

Antibiotics resistance constitutes a worse global health problem due to the over-use of antibiotics, horizontal gene transfer, and ultimate bacterial evolution. The discovery of bacteriophage that seemed to "eat bacteria" is usually attributed to Twort and d'Herelle in the early twentieth century [1]. Phage therapy accomplishes the natural predator-prey interaction between phage and its target bacteria and involves a purified cocktail to be administered to the patient directly and only lytic phage replicates exponentially within the bacteria after an immediate infection that is significant for therapy due to reduced transduction potential [2]. Additionally, bacteriophages can only replicate at the infection sites, which minimize allergic reactions, but antibiotics can spread throughout the body and ignore the site of infection. Lastly, bacteriophages are environmentally friendly and primarily based on natural selection and identify bacteria quickly compared to the new antibiotic, which may take several years and costly clinical trials [3]. Bacteriophage therapy has continued to be developed inside the former Soviet Union and Eastern countries, where inexpensive medical usage indicates their safety. However, reviews on their use have been restricted typically to observational studies [4]. Potential limitations of phage therapy are: (i) high specificity and narrow host range means that a single phage type cannot be used to treat the diversity of bacterial pathogens, (ii) even sometimes a phage cocktail is being required to treat a single bacterial pathogen, (iii) bacterial pathogens may acquire resistance against phages by changing their phage receptor, (iv) and until now, the human immune response to phages are not well understood or may cause the unwanted response [5]. The vast abundance and diversity of phages could 
make it a selective treatment instead of antibiotics for various purposes, including antibacterial therapy and decontamination, disease diagnosis, and control. Moreover, phage typing has been used in medical laboratories to identify the species and subtypes of bacteria like salmonella and bacillus [5]. The phage therapy has low toxicity and ease of production than antibiotics; since an antibiotic; acquired different mechanisms to counter bacterial defense, including extracellular bio-film production. Recent animal and human trials consider it significantly well-tolerated and hence are to be regarded as safe agents with a bright future as an alternative to chemical mediators [6]. In view of our current understanding of phage biology and their increased applications as therapeutic agents, phage therapy is considered to stand at a substantial level to prove its true potential.

\section{History of phage therapy}

Before the development of antibiotics, humans were considered a much suffered from infectious diseases and the discovery of antimicrobials in the $20^{\text {th }}$ century was considered a scientific revolution that significantly reduced the number of fatal cases. So, the frame has been labeled "antibiotic generation," and this type of therapy was the most successful chemotherapy in the field of medical history [7]. Due to this cause, new and alternate therapeutics must be considered, hence avoiding future mass affliction and health losses [8]. The discovery of bacteriophage and its potential uses aroused accidentally at the same time as an antibiotic [9]. In 1896, the British bacteriologist Ernest Hankin mentioned antibacterial activity against Vibrio cholera found in, India's Ganga, Jamna rivers, and two years later, Gamaleya, the Russian bacteriologist, found a comparable phenomenon while working with Bacillus subtilis [3]. From 1898 to 1918, others had similar observations of what is thought to be the bacteriophage phenomenon [3]. Bacteriophages were observed independently by Twort in London in 1915 and d'Herelle in Paris in 1917 [10]. Twort defined the "glassy transformation" of his micrococcal colonies add his definition. After he made his discovery, d'Herelle started to investigate infectious diseases in animals using bacteriophages [11]. Remarkably, bacteriophages from d'Herelle authentic start-up corporation remained commercially available to French physicians until 1978. Phage therapy persisted in being had and used clinically in France until the early 1990s [12]. In 1923, two physicians from Baylor University's college of drugs demonstrated the consequences of one of their phage remedy trials in the US, wherein they concluded that the bacteriophage holds enormous opportunities as a brand new fighter against infectious diseases [13]. However, bacteriophage treatment becomes a foreign and controversial subject, so antibiotics have become the popular alternate choice as it is less complicated challenging to produce than testing and finding the therapeutic bacteriophage of interest [14]. Different considerations encompass bacteriophage phenotype, mode of infection, host specificity, and a wide range of hosts that make them better for infections than antibiotics (Figure-1) [15].

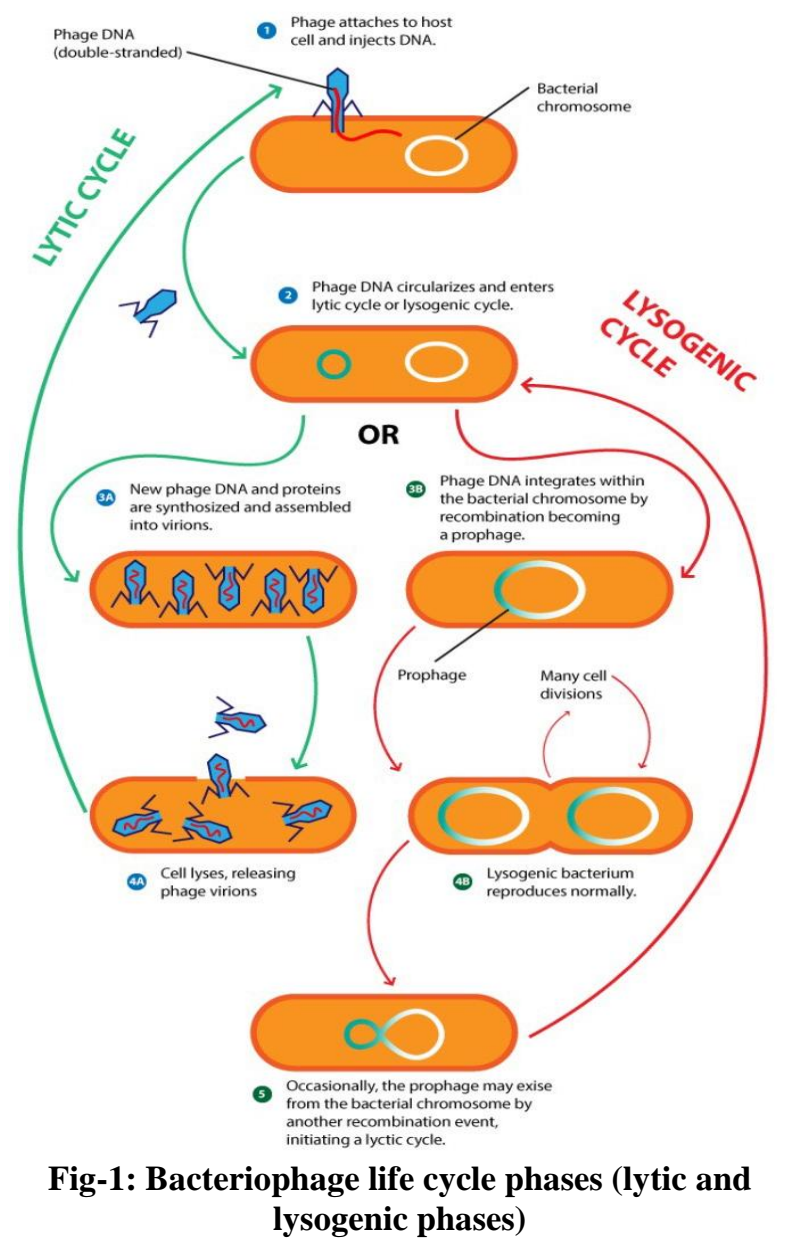

Applications in the food industry

Every day people use food products derived from plants and animal sources. Instead of adopting many hygienic measures, people are continuously suffering from different illnesses due to microbial populations transmitted through food. According to the world health organization (WHO), almost 1.8 million people died due to diarrheal diseases worldwide in 2005. In the USA alone, 3000 death was reported due to high microbial load in food [16]. Due to these microbes, usually, almost $25 \%$ of food products are lost annually [17]. Even due to advanced and modern technology, the reduction of microbial load in food is still a challenge throughout the globe [18]. Some most effective methods of reducing the microbial load include using biocides, disinfectants and adopting extreme hygienic measures [19]. From production until its consumption, food passes through different stages where chances of contamination are very high at each step, and due to over-use of disinfectants, microbes are now resistant to these preservatives. Primary food-borne pathogens affecting humankind include Salmonella, Clostridium 
Ali Raza et al., Sch Bull, Mar, 2021; 7(3): 27-37

perfringes, Listeria monocytogenes, Campylobacter, and Vibrio species. However, people usually dislike using these chemical preservatives in food products due to their adverse side effects [20]. Antibiotics can be used against these microorganisms, but these drugs are banned in food products. An alternative to antibiotics is the bacteriophages, and these are bacteria-eating viruses having lyses activity and can destroy the specific bacterial host [21]. So, bacteriophages have been indicated as a competitive tool against these microorganisms since these phages cause no damage to human cells [22]. In the following paragraphs, we summarize some applications of bacteriophages in the food industry.

\section{Campylobacter in the foodstuff}

One of the most common food-borne pathogens is Campylobacter, which causes enteric disease [23]. This genus consists of 17 species [24], but concerning humans, C. jejuni and $\mathrm{C}$. coli are the most common [25, 26]. This disease arises from eating infected poultry meat and its products $[27,28]$. In the UK, $80 \%$ of poultry birds harbor Campylobacter as a part of their normal intestinal flora, which is higher in European countries [29, 30]. Usually, these organisms present at a concentration of $7 \log ^{10} \mathrm{CFU} \mathrm{g}^{-\mathrm{g}}$ in poultry's caecum[31, 32]. Various approaches have been proposed, like increasing bio-security level to decrease the load of these pathogens, but it becomes quite expensive as even if only one bird is infected with these microbes, the whole of the poultry shed will be affected [33]. The development of antibiotic-resistant Campylobacter prompted bacteriophage therapy for the control of these organisms[10,34,35]. The bacteriophages that act against Campylobacter are double-stranded DNA, tailed with icosahedra heads and family members myoviridae. According to reports from the Russian federation, bacteriophages may belong to siphoviridae and podoviridae families [36]. Previously, lysogenic and temperate bacteriophages were described in C. featus. After the availability of genomic sequence data of several strains of $\mathrm{C}$. jejuni, it is now clear that prophages are present in some stains; RM1221 (mu-like sequence) has been identified [37]. Campylobacter bacteriophages have been obtained from their specific hosts like feces of pigs, cattle, and sheep [38-40], slaughterhouses, sewerage water, and excreta of chicken and poultry meat [41-43]. In an initial experiment, bacteriophages with average head sizes of $100 \mathrm{~nm}$ and a genome size of $138 \mathrm{~Kb}$ were given at a concentration of $3 \log _{10} \mathrm{CFUg}^{-\mathrm{FU}}$ was given, they reduce C.jejuni in the caecal contents after 48 hours as compared to non-treated chicken [32]. After many experiments, it was reported that the optimum dose rate for effective therapy is $7 \log _{10} \mathrm{PFU}$, any higher or lower dose than this will be less effective [32]. This less efficacy of bacteriophage at a higher dose could be due to that at a higher dose, and bacteriophages aggregate and show non-specific associations with non-infectious bacteria [44].

\section{E. coli 0157:H7 in foodstuff}

The toxin produced by E. coli is Shiga toxin $(\mathrm{O} 157: \mathrm{H} 7)$ that, even at a low dose, cause renal failure and hemolytic uremic syndrome [45, 46]. Usually, humans are taken-up by eating contaminated, partially cooked beef meat and drinking fresh juices [47, 48]. Meat pieces, when treated with Phage FAHEc1 $\left(10^{7} \mathrm{PFU} / \mathrm{ml}\right)$ at $5^{\circ} \mathrm{C}$ and $37^{\circ} \mathrm{C}$, a reduction in microbial load was seen as 4 and 2-3 log, respectively [49]. To boost up the action of bacteriophages, phage cocktail DT1 and DT6 were prepared to observed a reduction in the microbial load by 6.3 logs. Treating with phage cocktail and DT6 at 24c for 6 hours showed that cocktail action of bacteriophages (2.58 log reduction) was more prominent than the use of alone DT6 $(0.78$ $\log$ reduction) [50]. Further tests were performed to check the efficiency of alone and bacteriophage cocktails on milk samples. These tests indicated that the phage cocktail's action is more efficient than the bacteriophage alone [51]. For phage applications to E. coli O157:H7 in food, phage should be stable under various stress conditions, including temperature, $\mathrm{pH}$, water activity, and salt stress. Interestingly, under osmotic pressure, phage e4/1c showed better activity than phage e11/2 against E. coli O157:H7 [52]. For confirmation, further experiments with eight different virulent phages were performed, showing that $>94 \%$ of the tested strains of E. coli O157:H7 had an inhibited growth rate indicating bacteriophages' efficiency [51].

\section{Salmonella in the foodstuff}

Non-typhoid salmonellosis is caused by salmonella (S. enterica, S. typhimurium) having symptoms like diarrhea, fever, and gastric ulcers [48]. Mostly animal-based food products have been affected by this disease [53]. Although various natural and chemical preservatives were being used to preserve, food products, controlling this problem in food products is quite difficult [54]. Therefore, phages have been an important alternative method for controlling salmonellosis in food products [55]. F01 and E2 bacteriophages were used to treat salmonella in food products like hot dogs, sliced turkey breast, and mixed sea-food. It was observed that a low dose of bacteriophage $\left(3 \times 10^{8} \mathrm{PFU} / \mathrm{g}\right.$ of each food sample $)$ was given to contaminated cooked food and stored at $8^{\circ} \mathrm{C}$ for 6 days [56]. Furthermore, the skin samples infected with S.enteritidis were tested using a broad range phage wksl3 (107 PFU/ml), resulting in a $2.5 \log$ reduction in the bacterial count [57]. A genomic study of this phage showed that the bacteriophage does not have any deteriorating food elements. Hence it is safe to use in food items in human trials. Even at a high dose rate administered to infected mice, no abnormal changes or side effects were seen by bacteriophage therapy [57].To increase the efficiency against salmonella, a cocktail of 
bacteriophages was prepared, and it was showed that cocktail phage activity (4 log reduction) was much better than a single bacteriophage (2 -3 log reduction) [58]. After another series of experiments, a phage cocktail having three (UAB_Phi20, UAB_Phi78, and UAB_Phi87) and four phages (Felix01, phiSH19, phiSH17, and phiSH18) were prepared to have excellent efficiency against salmonella [59-61].

\section{Listeria monocytogenes in the foodstuff}

Another food-borne disease is listeriosis caused by Listeria monocytogenes, highly adapted to cold conditions and often found in cooked food products placed in refrigerators [62]. However, it is not very common, but it is perilous, with a fatality rate of about $45 \%$ [63]. For the treatment of this infection, phage A511 was used to treat both liquid and solid food products. To reduce the microbial load in liquid products below the detectable limit after 6 days at $6^{\circ} \mathrm{C}$, similarly, in solid food products, a reduction of $5 \operatorname{logs}$ was observed [64]. In another experiment, A511 phage showed host lytic activity by reducing the microbial load to $2.5 \operatorname{logs}$ [65]. After FDA approval, different phage products were prepared, including listex P100, to evaluate their effects on cheese. This treatment performed exceptionally well by reducing the load to $3.5 \mathrm{log}$, and high replication of microbial growth was utterly eradicated by using this phage at a concentration of $>10^{8}$ [66]. Animal research confirmed that this bacteriophage Listex P100 had no toxic effects and is highly safe for animals [66]. Further studies showed that despite high specificity, bacteriophages' activity depends upon the type of food items;e.g., the cocktail of phages (LM103 and LMP-102) showed 2 to $4.6 \mathrm{log}$ reduction in honeydew melon but showed the least action in apple slices [67].

\section{Staphylococcus aureus in the foodstuff}

$\mathrm{S}$. aureus is also a primary foodborne pathogen that is heat stable and produces toxins that are responsible for food poisoning, including nausea, vomiting, stomach pain, and diarrhea [68]. Moreover, due to the development of an antibiotic-resistant strain of Staphylococcus aureus, there was a demand to replace the antibiotic therapy [68, 69]. However, S. aureus phage can limit S. aureus, but it only works in milk after heat treatment [69]. This is because heat liable immunoglobulins inhibit the adhesion of phages to raw milk. However, a cocktail of two bacteriophages IPLA35 and IPLA88, reduced the growth of S. aureus on curd cheese by a concentration of 3.83 and 4.64, respectively [70]. Despite bacteriophage's effectiveness, it had no effects on cheese quality like starter strain and chemical properties of cheese [70]. Two cocktail phages TEAM/P68/LH1-MUT and phi812/44AHJD/phi2) were applied on cheese curd that reduced the microbial growth to $10^{6} \mathrm{CFU} / \mathrm{g}$ without any decrease in the titer of bacteriophage itself and with no release of any enterotoxins from S. aureus [71].

\section{Application of bacteriophage in aquaculture}

Aquaculture cultures have oceanic inhabitants and provide suitable mating and confinement conditions by delivering nutrients and medication to enhance their production like finfish, shellfish, and aquatic plants [72]. It becomes a significant problem caused by microbial diseases that gradually responsible for economic loss [73, 74]. Although the administration of antibiotics is the easiest and low-cost solution for bacterial infections, studies show that this approach has restricted success by developing multi-resistant bacteria, swapping of micro-organisms and eco-friendly impacts, and public health impacts $[75,76]$. Hence, it is required to trace new approaches to overcome and control microbial diseases in aquaculture. Bacteriophages were approved as new alternative remedies to prevent microbial infections from replacing the antibiotics and antiseptics and controlling the spread of multi-resistant bacteria in aquaculture. Phages are peculiar killers of pathogens as attractive agents for preventing bacterial infections in fish like Aeromonassalmonicida, A. hydrophila, Edwardsiella tarda, and Yersinia ruckeri [77].

\section{Lactococcus garvieae in aquaculture}

Lactococcus garvieae, earlier known as the Enterococcus seriolicida and Streptococcus responsible for lactococcosis in yellowtail (Seriola quinqueradiata) and other fish. It is a facultative anaerobic, Grampositive immoveable bacterium [78, 79]. It was derived from contaminated fish and belonged to the Siphoviridae family known as PLgY. The effects of this phage were studied in young yellowtail fish by the administration of the phage via 3 routes; oral, intraperitoneal (i.p.), and intubation by the anal route. After the i.p. injection of $10^{7.2}$ PFU of phage accompanied by i.p. injection with $10^{8.7} \mathrm{CFU}$ of $\mathrm{L}$. garvieae, it shows $90 \%$ positive results compared to the control group without any phage treatment. The most beneficial treatment of Lactococcus treatment was oral administration of phages in yellowtail fish. It is now considered a useful therapeutic and prophylaxis treatment [80].

\section{Streptococcus iniae in aquaculture}

Streptococcus iniae is a Gram-positive, zoonotic, and beta-hemolytic bacterium that causes streptococcosis in fish. When fish was administered with phage therapy by i.p. injection it reduces the mortality rate in fish as compared to those groups which are untreated and showed $100 \%$ mortality. During the experiment, the fish that died in the group of phage therapy were analyzed, and it was found that they consist of phage-resistant $\mathrm{S}$. iniae that shows that further studies are required to promote the effects of phage therapy [81]. 


\section{Pseudomonas aeruginosain aquaculture}

Pseudomonas aeruginosa is a Gram-negative, rod-shaped, and motile bacteria present in an aquatic environment and responsible for ulcerative lesions in freshwater cat-fish (Clarias gariepinus). A lytic phage was isolated from the sewage and was sequenced, and it shows a 99\% similarity with Pseudomonas phage PT2 and $98 \%$ similarity with Pseudomonas phage phiKMV. It was used to cure ulcerative lesions by swabbing at the surface of cat-fish [82]. The size of lesions was reduced in phage-treated fish after 8-10 days and was considered an effective therapy against P.aeruginosa [82].

\section{Recent advancements in bacteriophage therapy Phage pathogenic host array}

Phage having high specificity for their host by medical means as phage doesn't cause any harm to the healthy microflora of the human body [83]. There are two types of bacteriophages; (i) Broad range spectrum (ii) Narrow range spectrum. Broad range bacteriophage can bind to multiple receptor sites on the host cell surface (polyvalent phages), while narrow range can bind to only specific receptor sites (monovalent phages). Narrow range phage can be converted into a broad range phage by a point mutation in the receptor binding proteins present at the phages. Similarly, broad host range phage can also be limited to a narrow spectrum by mutating receptor binding protein (RBPs) [84].

\section{Enhancing bacteriophage ability as advanced therapeutics}

Phage therapy is one of the most convenient methods for the treatment of antibiotic-resistant bacteria. The stability of the drug is much more critical before its therapeutic application. The drug should be stable at room temperature, when stable once it gets inside the body, and become stable before it reaches its target site, and then perform its proper function effectively [83]. Protein-based drugs are more susceptible to denaturation due to high temperature, organic solvents, high $\mathrm{pH}$, and ionic deactivation. Phages also encounter external factors like mechanical force due to encapsulation or formulation that include shear forces during agitation and spraying force of atomization [85]. Since there is a decrease in phage titer and stability during this therapy, to enhance the stability of titer and increase the shelf life of these drugs, there is a need to focus on formulation methods [86].

\section{Spray drying}

The spray drying process is used for the liquid phase phages to convert into powdered form for a smooth inhalation for the treatment of infection in the respiratory tract. It can also be used in wound formulation, bandages, and the form of pills. By using trehalose and leucine, the phage belongs to the family of myovirideae in a spray-dried form [87].

\section{Phage in the form of microcrystals}

There are organic solvents like glycine trehalose or BSA (bovine serum albumin) to prepare spihoviridae microcrystals. There is up to 3 to $4 \log$ titer units decrease shown by microcrystals and stored for one month in ambient environments. This form is mostly used in the form of inhalant to treat respiratory disorders $[86,88]$.

\section{Encapsulation of phage}

Another way to overcome this barrier is to use the encapsulation of phage within liposomes that results in an extended period of stay in the caecum of chicken and hence reduce the number of bacteria in the gut [89]. The number of bacteria in blood, liver, spleen, lymph nodes, and feces was significantly reduced along with the level of cytokines in serum by phage treatment in mice. Compared to the oral route, intra-peritoneal and intra-venous administrations have shown quite improved results [85].

\section{Bacteriophage enhancement}

Modification of specific phages is made possible by the presence of genome sequences in the database available for public use, for research purposes in developing phage structural components, and for explaining the relationship between host bacteria and phages [90].

\section{CRISPR-Cas-Mediated Genome Engineering \\ Clustered regularly interspaced short} palindromic repeats (CRISPR) along with cas (CRISPR-associated) genes in bacteria and archaea form an adjustable/adaptive immune system, which protects the host cell from foreign DNA, for instance, the genome of phage [91]. In 2014, the first phage genome was edited by the CRISPR-CAS system to select mutant T7 phage, which carried a deletion of gene 1.7 that is considered a non-essential gene [92]. For the elimination of phage from the recombinants, CRISPR-Cas was used as a tool for screening. Plasmidmediated type 1 CRISPR Cas system was projected at gene 1.7 to cleaved and eliminated. WT phage T7mutant phage having no gene 1.7 shows resistance against Cas 9 complex, and it propagates without any effect on it [92]. Streptococcus thermophiles, Streptococcus pyogenes, and listeria monocytogenes were used to make a unique platform for the engineering of their respective phages [92].

\section{Endolysins; an evolution to phage therapy}

Besides implementing the entire bacteriophage as a substitute for typical antibiotics, there has been a contemporary advancement in utilizing the phages and phage-acquired products, explicitly endolysins as antimicrobial agents [93, 94]. These proteins frequently comprehend enzymatic integrants that include virionassociated peptidoglycan hydrolases, also designated as lytic structural proteins that destroy the bacterial cell 
wall peptidoglycans, thus enabling the penetration of phage DNA at the origination of the infection. In the termination of the lytic cycle, descendant virions elude the host cell with the aid of endolysins, i.e., phageencoded peptidoglycan hydrolase [94]. Endolysins integrate into the cytoplasm and reach the peptidoglycans with the assistance of another phage protein called holin (monomeric transmembrane proteins) through a greatly supervised mechanism. As Gram-positive pathogens lack a protective outer membrane, the exogenous application of endolysins leads to rapid and effective lysis, hence increases the interest of endolysins as dormant therapeutic [95].

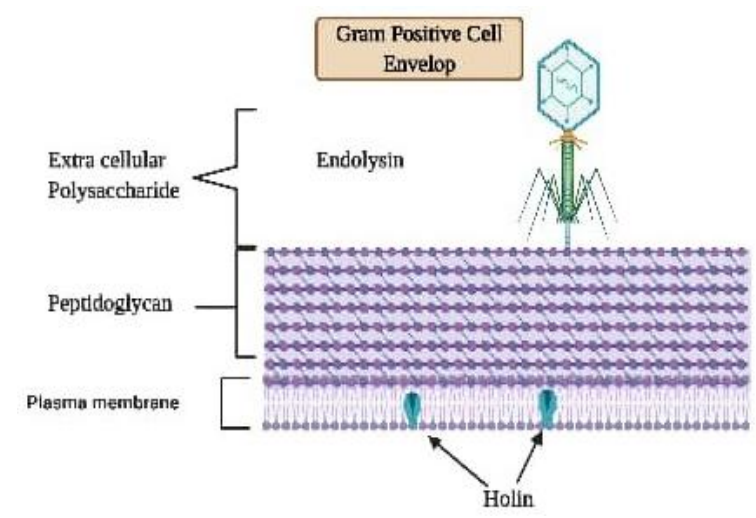

Fig-2: Gram (+) and Gram (-) endolysins
Differences in Gram (+) and Gram (-) endolysins

These two dominant bacterial groups to possess different endolysins due to variations in the cell wall composition of gram-positive and gram-negative bacteria. Gram-positive endolysins are composed of two definite domains, i.e., an enzymatically active domain (EAD) and a cell-binding domain (CBD) [94]. EAD destroys bonds of bacterial peptidoglycans, and CBD attaches the endolysin with the cell wall of bacteria to lessen the diffusion in the cell and destroys the surrounding cells. In comparison, Gram-negative bacteria contain only the EAD domain and lack the CBD domain in their structure (Figure-2) [94, 96, 97].

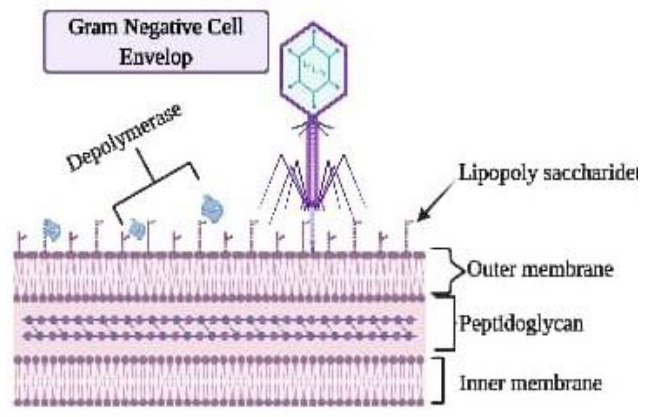

\section{Endolysins are superior to antibiotics}

Endolysins also called enzybiotics enzymes to have certain advantages over traditional antibiotics, like instant host elimination, specific host selectivity, protection of healthy microflora, little probability of acquiring resistance, effectiveness against multi-drugresistant bacteria, interdependent with other antibacterial agents, and efficacious in bio-films along with mucosal surfaces [96, 97].

\section{Advantages of endolysins over the entire phage}

The advantages of utilizing endolysins compared to the entire bacteriophage are that it involves the evacuation of the genome from the therapeutic, therefore eradicating the probability of genome transfer and mutation [93]. Moreover, there are no significant resistance cases of endolysins that explain that they are extremely conserved and highly specific to their bacterial host $[93,96]$.

\section{Bacteriophage therapy in human diseases}

A bacteriophage is considered to be the latent antibacterial therapeutics for the cure of several infections in human beings. Primarily for the treatment of acute intestinal and skin infection, the clinical application of bacteriophages was designed. Later in the $20^{\text {th }}$ century, bacteriophages are used in the USSR surgical practice to cure post-infective complications and purulent wounds [98]. Moreover, for clinical application phage preparation accepted has been produced in Poland, Georgia, Russian Federation, and many studies on phage therapy have been documented in these countries [2, 34, 99-101], Currently, the outcomes of bacteriophage and phage cocktail application for the cure of several infections have been documented in series of clinical cases and many clinical trials [102-104]. Notably, as mono-therapy, phage therapy was used, whereas, for the complex treatments, combined phage and antibiotics have been used. The survey exposed that combined treatment compared to antibiotics alone declined the healing time up-to 1.2-2.5 times [105]. This progressive effect was possibly due to the immune status of the patient. Bacteriophage impacts the regenerative processes in the wound and damages the biofilm [106-108]. Hence, it was concluded that to avoid the complications of an infected wound, a single application of bacteriophage is not sufficient [109]. In cancer patients, for the cure of post-operative wounds, phage therapy was used for fast cleaning of the wounds from granulation, accumulation of purulent masses, and healing the wounds without any deformed scar compared to the cancer patient that was treated only with antibiotics. Additionally, phage therapy could cure burns and avoid sepsis [110-112]. In other studies, it was found that in the complex therapy (phage+antibiotic), bacteriophage application provides $\mathrm{n}$ excellent clinical dynamics as compared to antibiotics used in the patients infected with burns [113]. In phage therapy, the phage preparation dose is significantly essential, and the therapeutic level must be higher than $106 \mathrm{pfu} / \mathrm{ml}$. In most cases, a high concentrated phage preparation is used, but BS24 phage is applied even at a 
Ali Raza et al., Sch Bull, Mar, 2021; 7(3): 27-37

low-level of $103 \mathrm{pfu} / \mathrm{ml}$ proved effective results [111]. Furthermore, even with the use of cocktail BFC-1 at a high-level of $109 \mathrm{pfu} / \mathrm{ml}$, no convincing results were observed. It was thus concluded that these preliminary results might be due to former topical and systemic antibiotic therapy causing an interruption in the phage therapy or might be due to inappropriate pharmaceutical preparation of BFC-1 [110].

\section{CONCLUSIONS AND FURTHER STUDIES}

Since now, many studies have exhibited the therapeutic application of endolysins in tackling drugresistant infections. Nonetheless, few endolysins have some restrictions, i.e., less in-vivo half-life and the formation of inflammatory cytokines and neutralizing antibodies. Moreover, since endolysins have not been analyzed in animal models; hence, it limits their clinical application. Future proposals like protein engineering, development in their delivery systems, and targeted delivery to the infection site are the current needs [96, 97]. The results of phage therapy depend on the number and titer of phage applied, convenience and sensitivity of bacterial host of phage, route of phage administration, and the duration of treatment. In short, these bactericidal agents have low inherent toxicity, minimal disruption for the normal flora of the body, reduced potential to induce the resistance, limit the cross-resistance with antibiotics and have preparation and application versatility.

Conflicts of interest: The authors announce that they have no challenging interests.

Acknowledgments: The authors wish to thanks all other co-authors for providing guidance and support

\section{REFERENCES}

1. Lu, T. K., \& Koeris, M. S. (2011). The next generation of bacteriophage therapy. Current opinion in microbiology, 14(5), 524-531.

2. Chanishvili, N., \& Aminov, R. (2019). Bacteriophage therapy: Coping with the growing antibiotic resistance problem. Microbiology Australia, 40(1), 5-7.

3. Golkar, Z., Bagasra, O., \& Pace, D. G. (2014). Bacteriophage therapy: a potential solution for the antibiotic resistance crisis. The Journal of Infection in Developing Countries, 8(02), 129136.

4. Henry, B. A. H. (2019). A Case Series of Emergency Investigational New Drug Applications for Bacteriophages Treating Recalcitrant Multi-drug Resistant Bacterial Infections: Confirmed Safety and a Signal of Efficacy. Journal of Intensive and Critical Care, 5(2), 11.

5. Nikolich, M. P., \& Filippov, A. A. (2020). Bacteriophage therapy: Developments and directions. Antibiotics, 9(3), 135.
6. Burrowes, B., Harper, D. R., Anderson, J., McConville, M., \& Enright, M. C. (2011). Bacteriophage therapy: potential uses in the control of antibiotic-resistant pathogens. Expert review of anti-infective therapy, 9(9), 775-785.

7. Álvarez, D., Caro, M. R., Buendía, A. J., Schnee, C., Ortega, N., Murcia-Belmonte, A., \& Salinas, J. (2019). Effect of female sex hormones on the developmental cycle of Chlamydia abortus compared to a penicillin-induced model of persistent infection. BMC veterinary research, 15(1), 1-11.

8. Ventola, C. L. (2015). The antibiotic resistance crisis: part 1: causes and threats. Pharmacy and therapeutics, 40(4), 277-283.

9. Lin, D. M., Koskella, B., \& Lin, H. C. (2017). Phage therapy: An alternative to antibiotics in the age of multi-drug resistance. World journal of gastrointestinal pharmacology and therapeutics, 8(3), 162.

10. Summers, W. C. (2001). Bacteriophage therapy. Annual Reviews in Microbiology, 55(1), 437-451.

11. Squires, R. A. (2018). Bacteriophage therapy for management of bacterial infections in veterinary practice: what was once old is new again. New Zealand veterinary journal, 66(5), 229-235.

12. Abedon, S. T., Kuhl, S. J., Blasdel, B. G., \& Kutter, E. M. (2011). Phage treatment of human infections. Bacteriophage, 1(2), 66-85.

13. Ho, K. (2001). Bacteriophage therapy for bacterial infections: rekindling a memory from the preantibiotics era. Perspectives in Biology and Medicine, 44(1), 1-16.

14. Wittebole, X., De Roock, S., \& Opal, S. M. (2014). A historical overview of bacteriophage therapy as an alternative to antibiotics for the treatment of bacterial pathogens. Virulence, 5(1), 226-235.

15. Saha, D., \& Mukherjee, R. (2019). Ameliorating the antimicrobial resistance crisis: phage therapy. IUBMB life, 71(7), 781-790.

16. Scallan, E., Hoekstra, R. M., Angulo, F. J., Tauxe, R. V., Widdowson, M. A., Roy, S. L., ... \& Griffin, P. M. (2011). Foodborne illness acquired in the United States-major pathogens. Emerging infectious diseases, 17(1), 7.

17. Sarhan, W. A., \& Azzazy, H. M. (2015). Phage approved in food, why not as a therapeutic?. Expert review of anti-infective therapy, 13(1), 91-101.

18. Rocourt, J., Moy, G., Vierk, K., \& Schlundt, J. (2003). The present state of foodborne disease in OECD countries. http://www.who.int/foodsafety (accessed 20 February 2021).

19. Maillard, J. Y. (2005). Antimicrobial biocides in the healthcare environment: efficacy, usage, policies, and perceived problems. Therapeutics and clinical risk management, 1(4), 307. 
Ali Raza et al., Sch Bull, Mar, 2021; 7(3): 27-37

20. Pawlowska, A. M., Zannini, E., Coffey, A., \& Arendt, E. K. (2012). "Green preservatives": combating fungi in the food and feed industry by applying antifungal lactic acid bacteria. Advances in food and nutrition research, 66, 217-238.

21. Sulakvelidze, A., \& Kutter, E. (2004). Bacteriophage Therapy in Humans, in: Bacteriophages, CRC Press. https://doi.org/10.1201/9780203491751.ch14.

22. McCallin, S., Sarker, S. A., Barretto, C., Sultana, S., Berger, B., Huq, S., ... \& Brüssow, H. (2013). Safety analysis of a Russian phage cocktail: from metagenomic analysis to oral application in healthy human subjects. Virology, 443(2), 187196.

23. Adak, G. K., Meakins, S. M., Yip, H., Lopman, B. A., \& O'Brien, S. J. (2005). Disease risks from foods, England and Wales, 1996-2000. Emerging infectious diseases, 11(3), 365-372.

24. Korczak, B. M., Stieber, R., Emler, S., Burnens, A. P., Frey, J., \& Kuhnert, P. (2006). Genetic relatedness within the genus Campylobacter inferred from rpoB sequences. International journal of systematic and evolutionary microbiology, 56(5), 937-945.

25. Acheson, D., \& Allos, B. M. (2001). Campylobacter jejuni infections: update on emerging issues and trends. Clinical infectious diseases, 32(8), 1201-1206.

26. Miller, W. G., Mandrell, R., Ketley, J., \& Konkel, M. (2005). Prevalence of Campylobacter in the food and water supply: incidence, outbreaks, isolation and detection. Undefined.

27. Wingstrand, A., Neimann, J., Engberg, J., Nielsen, E. M., Gerner-Smidt, P., Wegener, H. C., \& Mølbak, K. (2006). Fresh chicken as main risk factor for campylobacteriosis, Denmark. Emerging infectious diseases, 12(2), 280-284.

28. Lindqvist, R., \& Lindblad, M. (2008). Quantitative risk assessment of thermophilic Campylobacter spp. and cross-contamination during handling of raw broiler chickens evaluating strategies at the producer level to reduce human campylobacteriosis in Sweden. International journal of food microbiology, 121(1), 41-52.

29. Lahuerta, A., Westrell, T., Takkinen, J., Boelaert, F., Rizzi, V., Helwigh, B., ... \& Mäkelä, P. (2011). Zoonoses in the European Union: origin, distribution and dynamics-the EFSA-ECDC summary report 2009. Eurosurveillance, 16(13), 19832.

30. European Food Safety Authority (EFSA), Boelaert, F., Hugas, M., Ortiz Pelaez, A., Rizzi, V., Stella, P., \& Van Der Stede, Y. (2016). The European Union summary report on data of the surveillance of ruminants for the presence of transmissible spongiform encephalopathies (TSEs) in 2015. EFSA Journal, 14(12), e04643.
31. Rudi, K., Høidal, H. K., Katla, T., Johansen, B. K., Nordal, J., \& Jakobsen, K. S. (2004). Direct real-time PCR quantification of Campylobacter jejuni in chicken fecal and cecal samples by integrated cell concentration and DNA purification. Applied and Environmental Microbiology, 70(2), 790-797.

32. Carrillo, C. L., Atterbury, R. J., El-Shibiny, A., Connerton, P. L., Dillon, E., Scott, A., \& Connerton, I. F. (2005). Bacteriophage therapy to reduce Campylobacter jejuni colonization of broiler chickens. Applied and environmental microbiology, 71(11), 6554-6563.

33. Newell, D. G., \& Fearnley, C. J. A. E. M. (2003). Sources of Campylobacter colonization in broiler chickens. Applied and environmental microbiology, 69(8), 4343-4351.

34. Sulakvelidze, A., Alavidze, Z., \& Morris, J. G. (2001). Bacteriophage therapy. Antimicrobial agents and chemotherapy, 45(3), 649-659.

35. Monk, A. B., Rees, C. D., Barrow, P., Hagens, S., \& Harper, D. R. (2010). Bacteriophage applications: where are we now?. Letters in applied microbiology, 51(4), 363-369.

36. Connerton, P. L., Timms, A. R., \& Connerton, I. F. (2011). Campylobacter bacteriophages and bacteriophage therapy. Journal of applied microbiology, 111(2), 255-265.

37. Fouts, D. E., Mongodin, E. F., Mandrell, R. E., Miller, W. G., Rasko, D. A., Ravel, J., ... \& Nelson, K. E. (2005). Major structural differences and novel potential virulence mechanisms from the genomes of multiple Campylobacter species. PLoS Biol, 3(1), e15.

38. Bryner, J. H., Ritchie, A. E., Foley, J. W., \& Berman, D. T. (1970). Isolation and characterization of a bacteriophage for Vibrio fetus. Journal of virology, 6(1), 94-99.

39. Bryner, J. H., Ritchie, A. E., Booth, G. D., \& Foley, J. W. (1973). Lytic activity of vibrio phages on strains of Vibrio fetus isolated from man and animals. Applied microbiology, 26(3), 404-409.

40. Border, M., Myers, L. L., \& Firehammer, B. D. (1974). Bactericidal activity of blood of rabbits vaccinated with homologous antigens of Campylobacter fetus (Vibrio fetus). Infection and immunity, 10(3), 416-421.

41. Grajewski, B. A., Kusek, J. W., \& Gelfand, H. M. (1985). Development of a bacteriophage typing system for Campylobacter jejuni and Campylobacter coli. Journal of clinical microbiology, 22(1), 13-18.

42. Salama, S., Bolton, F. J., \& Hutchinson, D. N. (1989). Improved method for the isolation of Campylobacter jejuni and Campylobacter coli bacteriophages. Letters in applied microbiology, 8(1), 5-7.

43. Khakhria, R., \& Lior, H. (1992). Extended phagetyping scheme for Campylobacter jejuni and 
Campylobacter coli. Epidemiology \& Infection, 108(3), 403-414.

44. Rabinovitch, A., Aviram, I., \& Zaritsky, A. (2003). Bacterial debris-an ecological mechanism for coexistence of bacteria and their viruses. Journal of Theoretical Biology, 224(3), 377-383.

45. Kaper, J. B. (1998). Enterohemorrhagic Escherichia coli. Current opinion in microbiology, 1(1), 103-108.

46. Newell, D. G., Koopmans, M., Verhoef, L., Duizer, E., Aidara-Kane, A., Sprong, H., ... \& Kruse, H. (2010). Food-borne diseases-the challenges of 20 years ago still persist while new ones continue to emerge. International journal of food microbiology, 139, S3-S15.

47. Cody, S. H., Glynn, M. K., Farrar, J. A., Cairns, K. L., Griffin, P. M., Kobayashi, J., ... \& Vugia, D. J. (1999). An outbreak of Escherichia coli O157: H7 infection from unpasteurized commercial apple juice. Annals of Internal Medicine, 130(3), 202-209.

48. Endersen, L., O'Mahony, J., Hill, C., Ross, R. P., McAuliffe, O., \& Coffey, A. (2014). Phage therapy in the food industry. Annual review of food science and technology, 5, 327-349.

49. Hudson, J. A., Billington, C., Cornelius, A. J., Wilson, T., On, S. L. W., Premaratne, A., \& King, N. J. (2013). Use of a bacteriophage to inactivate Escherichia coli O157: H7 on beef. Food Microbiology, 36(1), 14-21.

50. Tomat, D., Mercanti, D., Balagué, C., \& Quiberoni, A. (2013). Phage biocontrol of enteropathogenic and $\mathrm{S}$ higa toxin- producing Escherichia coli during milk fermentation. Letters in Applied Microbiology. 57, 3-10.

51. Viazis, S., Akhtar, M., Feirtag, J., \& DiezGonzalez, F. (2011). Reduction of Escherichia coli O157: H7 viability on hard surfaces by treatment with a bacteriophage mixture. International journal of food microbiology, 145(1), 37-42.

52. Coffey, J. E., Hammer, D., Levin, D. M., \& Grant, T. (2011). The missing disciplinary substance of formative assessment. Journal of research in science teaching, 48(10), 1109-1136.

53. Forshell, L. P., \& Wierup, M. (2006). Salmonella contamination: a significant challenge to the global marketing of animal food products. Rev. sci. tech. Off. int. Epiz, 25(2), 541-554.

54. Sharma, M. (2013). Lytic bacteriophages: potential interventions against enteric bacterial pathogens on produce. Bacteriophage, 3(2), e25518.

55. von lytischen Bakteriophagen, P. H. A. (2013). Post-harvest application of lytic bacteriophages for biocontrol of food-borne pathogens and spoilage bacteria. Berliner und Münchener Tierärztliche Wochenschrift, 126(9/10), 357-369.
56. Guenther, S., Herzig, O., Fieseler, L., Klumpp, J., \& Loessner, M. J. (2012). Biocontrol of Salmonella Typhimurium in RTE foods with the virulent bacteriophage FO1-E2. International Journal of Food Microbiology, 154(1-2), 66-72.

57. Kang, H. W., Kim, J. W., Jung, T. S., \& Woo, G. J. (2013). wksl3, a New biocontrol agent for Salmonella enterica serovars enteritidis and typhimurium in foods: characterization, application, sequence analysis, and oral acute toxicity study. Applied and environmental microbiology, 79(6), 1956-1968.

58. Bao, H., Zhang, P., Zhang, H., Zhou, Y., Zhang, L., \& Wang, R. (2015). Bio-control of Salmonella Enteritidis in foods using bacteriophages. Viruses, 7(8), 4836-4853.

59. Hooton, S. P., Atterbury, R. J., \& Connerton, I. F. (2011). Application of a bacteriophage cocktail to reduce Salmonella Typhimurium U288 contamination on pig skin. International journal of food microbiology, 151(2), 157-163.

60. Bardina, C., Spricigo, D. A., Cortés, P., \& Llagostera, M. (2012). Significance of the bacteriophage treatment schedule in reducing Salmonella colonization of poultry. Applied and environmental microbiology, 78(18), 6600-6607.

61. Spricigo, D. A., Bardina, C., Cortés, P., \& Llagostera, M. (2013). Use of a bacteriophage cocktail to control Salmonella in food and the food industry. International journal of food microbiology, 165(2), 169-174.

62. de Noordhout, C. M., Devleesschauwer, B., Angulo, F. J., Verbeke, G., Haagsma, J., Kirk, M., ... \& Speybroeck, N. (2014). The global burden of listeriosis: a systematic review and metaanalysis. The Lancet Infectious Diseases, 14(11), 1073-1082.

63. Siegman-Igra, Y., Levin, R., Weinberger, M., Golan, Y., Schwartz, D., Samra, Z., ... \& Shohat, T. (2002). Listeria monocytogenes infection in Israel and review of cases worldwide. Emerging infectious diseases, 8(3), 305-310.

64. Guenther, S., Huwyler, D., Richard, S., \& Loessner, M. J. (2009). Virulent bacteriophage for efficient biocontrol of Listeria monocytogenes in ready-to-eat foods. Applied and environmental microbiology, 75(1), 93-100.

65. Bigot, B., Lee, W. J., McIntyre, L., Wilson, T., Hudson, J. A., Billington, C., \& Heinemann, J. A. (2011). Control of Listeria monocytogenes growth in a ready-to-eat poultry product using a bacteriophage. Food Microbiology, 28(8), 14481452.

66. Carlton, R. M., Noordman, W. H., Biswas, B., De Meester, E. D., \& Loessner, M. J. (2005). Bacteriophage P100 for control of Listeria monocytogenes in foods: genome sequence, bioinformatic analyses, oral toxicity study, and 
Ali Raza et al., Sch Bull, Mar, 2021; 7(3): 27-37

application. Regulatory Toxicology and Pharmacology, 43(3), 301-312.

67. Oliveira, M., Viñas, I., Colàs, P., Anguera, M., Usall, J., \& Abadias, M. (2014). Effectiveness of a bacteriophage in reducing Listeria monocytogenes on fresh-cut fruits and fruit juices. Food microbiology, 38, 137-142.

68. Kadariya, J., Smith, T. C., \& Thapaliya, D. (2014). Staphylococcus aureus and staphylococcal foodborne disease: an ongoing challenge in public health. BioMed research international, 2014.

69. O'flaherty, S., Coffey, A., Meaney, W. J., Fitzgerald, G. F., \& Ross, R. P. (2005). Inhibition of bacteriophage $\mathrm{K}$ proliferation on Staphylococcus aureus in raw bovine milk. Letters in applied microbiology, 41(3), 274-279.

70. Bueno, E., García, P., Martínez, B., \& Rodríguez, A. (2012). Phage inactivation of Staphylococcus aureus in fresh and hard-type cheeses. International journal of food microbiology, 158(1), 23-27.

71. El Haddad, L., Roy, J. P., Khalil, G. E., St-Gelais, D., Champagne, C. P., Labrie, S., \& Moineau, S. (2016). Efficacy of two Staphylococcus aureus phage cocktails in cheese production. International journal of food microbiology, 217, 7-13.

72. Pillay, T. V. R., \& Kutty, M. N. (2005). Aquaculture: principles and practices., Aquaculture: Principles and Practices.

73. Hektoen, H., Berge, J. A., Hormazabal, V., \& Yndestad, M. (1995). Persistence of antibacterial agents in marine sediments. Aquaculture, 133(34), 175-184.

74. Berthe, F. (2005, November). Diseases in mollusc hatcheries and their paraedox in health management. In Diseases in Asian Aquaculture.

75. Nakai, T., \& Park, S. C. (2002). Bacteriophage therapy of infectious diseases in aquaculture. Research in microbiology, 153(1), 13-18.

76. Perreten, V. (2005). Resistance in the food chain and in bacteria from animals: relevance to human infections. Frontiers in antimicrobial resistance: a tribute to Stuart B. Levy, 446-464.

77. Park, K. H., Matsuoka, S., Nakai, T., \& Muroga, K. (1997). A virulent bacteriophage of Lactococcus garvieae (formerly Enterococcus seriolicida) isolated from yellowtail Seriola quinqueradiata. Diseases of aquatic organisms, 29(2), 145-149.

78. Park, K. H., Matsuoka, S., Nakai, T., \& Muroga, K. (1997). A virulent bacteriophage of Lactococcus garvieae (formerly Enterococcus seriolicida) isolated from yellowtail Seriola quinqueradiata. Diseases of aquatic organisms, 29(2), 145-149.

79. Austin, B., \& Austin, D. A. (2016). Bacterial fish pathogens: Disease of farmed and wild fish, sixth edition, Springer International Publishing. https://doi.org/10.1007/978-3-319-32674-0.

80. Nakai, T., Sugimoto, R., Park, K. H., Matsuoka, S., Mori, K. I., Nishioka, T., \& Maruyama, K. (1999). Protective effects of bacteriophage on experimental Lactococcus garvieae infection in yellowtail. Diseases of aquatic organisms, 37(1), 33-41.

81. Matsuoka, S., Hashizume, T., Kanzaki, H., Iwamoto, E., Park, S. C., Yoshida, T., \& Nakai, T. (2007). Phage therapy against $\beta$-hemolytic streptococcicosis of Japanese flounder Paralichthys olivaceus. Fish Pathology. 42.

82. Khairnar, K., Raut, M. P., Chandekar, R. H., Sanmukh, S. G., \& Paunikar, W. N. (2013). Novel bacteriophage therapy for controlling metallobeta-lactamase producing Pseudomonas aeruginosa infection in catfish. BMC veterinary research, 9(1), 1-9.

83. Bárdy, P., Pantůček, R., Benešík, M., \& Doškař, J. (2016). Genetically modified bacteriophages in applied microbiology. Journal of Applied Microbiology, 121(3), 618-633.

84. de Jonge, P. A., Nobrega, F. L., Brouns, S. J., \& Dutilh, B. E. (2019). Molecular and evolutionary determinants of bacteriophage host range. Trends in microbiology, 27(1), 51-63.

85. Malik, D. J., Sokolov, I. J., Vinner, G. K., Mancuso, F., Cinquerrui, S., Vladisavljevic, G. T., ... \& Kirpichnikova, A. (2017). Formulation, stabilisation and encapsulation of bacteriophage for phage therapy. Advances in colloid and interface science, 249, 100-133.

86. Vandenheuvel, D., Lavigne, R., \& Brüssow, H. (2015). Bacteriophage therapy: advances in formulation strategies and human clinical trials. Annual review of virology, 2, 599-618.

87. Malik, D. (2020). Bacteriophage encapsulation using spray drying for phage therapy. Current Issues in Molecular Biology. 40, 303-316.

88. Harada, L. K., Silva, E. C., Campos, W. F., Del Fiol, F. S., Vila, M., Dąbrowska, K., ... \& Balcão, V. M. (2018). Biotechnological applications of bacteriophages: State of the art. Microbiological research, 212, 38-58.

89. Brown, T. L., Petrovski, S., Chan, H. T., Angove, M. J., \& Tucci, J. (2018). Semi-solid and solid dosage forms for the delivery of phage therapy to epithelia. Pharmaceuticals, 11(1), 26.

90. Pires, D. P., Cleto, S., Sillankorva, S., Azeredo, J., \& Lu, T. K. (2016). Genetically engineered phages: a review of advances over the last decade. Microbiology and Molecular Biology Reviews, 80(3), 523-543.

91. Westra, E. R., Buckling, A., \& Fineran, P. C. (2014). CRISPR-Cas systems: beyond adaptive immunity. Nature reviews Microbiology, 12(5), 317-326. 
92. Chen, Y., Batra, H., Dong, J., Chen, C., Rao, V. B., \& Tao, P. (2019). Genetic engineering of bacteriophages against infectious diseases. Frontiers in microbiology, 10, 954.

93. Hathaway, H., Milo, S., Sutton, J. M., \& Jenkins, T. A. (2017). Recent advances in therapeutic delivery systems of bacteriophage and bacteriophage-encoded endolysins. Therapeutic delivery, 8(7), 543-556.

94. Fernández-Ruiz, I., Coutinho, F. H., \& RodriguezValera, F. (2018). Thousands of novel endolysins discovered in uncultured phage genomes. Frontiers in microbiology, 9, 1033.

95. Kashani, H. H., Schmelcher, M., Sabzalipoor, H., Hosseini, E. S., \& Moniri, R. (2018). Recombinant endolysins as potential therapeutics against antibiotic-resistant Staphylococcus aureus: current status of research and novel delivery strategies. Clinical microbiology reviews, 31(1).

96. Gondil, V. S., Kalaiyarasan, T., Bharti, V. K., \& Chhibber, S. (2019). Antibiofilm potential of Seabuckthorn silver nanoparticles (SBT@ AgNPs) against Pseudomonas aeruginosa. 3 Biotech, 9(11), 1-13.

97. Gondil, V. S., Harjai, K., \& Chhibber, S. (2020). Endolysins as emerging alternative therapeutic agents to counter drug-resistant infections. International journal of antimicrobial agents, 55(2), 105844.

98. Morozova, V. V., Kozlova, Y. N., Ganichev, D. A., \& Tikunova, N. V. (2018). Bacteriophage treatment of infected diabetic foot ulcers. In Bacteriophage Therapy (pp. 151-158). Humana Press, New York, NY.

99. Weber-Dạbrowska, B., Mulczyk, M., \& Górski, A. (2000). Bacteriophage therapy of bacterial infections: An update of our institute's experience, Archivum Immunologiae et Therapiae Experimentalis. 48, 547-551.

100. Międzybrodzki, R., Borysowski, J., WeberDąbrowska, B., Fortuna, W., Letkiewicz, S., Szufnarowski, K., ... \& Górski, A. (2012). Clinical aspects of phage therapy. Advances in virus research, 83, 73-121.

101. Gorski, A., Międzybrodzki, R., Borysowski, J., Dąbrowska, K., Wierzbicki, P., Ohams, M., ... \& Kłosowska, D. (2012). Phage as a modulator of immune responses: practical implications for phage therapy. Advances in virus research, 83, 4171.

102. Jennes, S., Merabishvili, M., Soentjens, P., Pang, K. W., Rose, T., Keersebilck, E., ... \& Pirnay, J. P. (2017). Use of bacteriophages in the treatment of colistin-only-sensitive Pseudomonas aeruginosa septicaemia in a patient with acute kidney injury - a case report. Critical Care, 21(1), 1-3.

103. Fish, R., Kutter, E., Wheat, G., Blasdel, B., Kutateladze, M., \& Kuhl, S. (2016).
Bacteriophage treatment of intransigent diabetic toe ulcers: a case series. Journal of wound care, 25(Sup7), S27-S33.

104. Wright, A., Hawkins, C. H., Änggård, E. E., \& Harper, D. R. (2009). A controlled clinical trial of a therapeutic bacteriophage preparation in chronic otitis due to antibiotic- resistant Pseudomonas aeruginosa; a preliminary report of efficacy. Clinical otolaryngology, 34(4), 349-357.

105. Morozova, V. V., Vlassov, V. V., \& Tikunova, N. V. (2018). Applications of bacteriophages in the treatment of localized infections in humans. Frontiers in microbiology, 9, 1696.

106. Van Belleghem, J. D., Clement, F., Merabishvili, M., Lavigne, R., \& Vaneechoutte, M. (2017). Proand anti-inflammatory responses of peripheral blood mononuclear cells induced by Staphylococcus aureus and Pseudomonas aeruginosa phages. Scientific reports, 7(1), 1-13.

107. Górski, A., Dąbrowska, K., Międzybrodzki, R., Weber-Dąbrowska, B., Łusiak-Szelachowska, M., Jończyk-Matysiak, E., \& Borysowski, J. (2017). Phages and immunomodulation. Future microbiology, 12(10), 905-914.

108. Międzybrodzki, R., Fortuna, W., WeberDąbrowska, B., \& Górski, A. (2009). A retrospective analysis of changes in inflammatory markers in patients treated with bacterial viruses. Clinical and experimental medicine, 9(4), 303-312.

109. Briusov, P. G., Zubritskiū, V. F., Islamov, R. N., Nizovoř, A. V., \& Fominykh, E. M. (2011). Phagoprophylaxis and bacteriophage treatment of surgical infections. Voenno-meditsinskii zhurnal, 332(4), 34-39.

110. Rose, T., Verbeken, G., De Vos, D., Merabishvili, M., Vaneechoutte, M., Lavigne, R., ... \& Pirnay, J. P. (2014). Experimental phage therapy of burn wound infection: difficult first steps. International journal of burns and trauma, 4(2), 66-73.

111. Marza, J. S., Soothill, J. S., Boydell, P., \& Collyns, T. A. (2006). Multiplication of therapeutically administered bacteriophages in Pseudomonas aeruginosa infected patients. Burns, 32(5), 644-646.

112. Lazareva, E. B., Smirnov, S. V., Khvatov, V. B., Spiridonova, T. G., Bitkova, E. E., Darbeeva, O. S., ... \& Men'shikov, D. D. (2001). Efficacy of bacteriophages in complex treatment of patients with burn wounds. Antibiotiki i khimioterapiia= Antibiotics and chemoterapy [sic], 46(1), 10-14.

113. Lazareva, E. B., Smirnov, S. V., Khvatov, V. B., Spiridonova, T. G., Bitkova, E. E., Darbeeva, O. S., ... \& Men'shikov, D. D. (2001). Efficacy of bacteriophages in complex treatment of patients with burn wounds. Antibiotiki i khimioterapiia= Antibiotics and chemoterapy [sic], 46(1), 10-14. 